\title{
GENDER INEQUALITY, COOPERATION AND ENVIRONMENTAL SUSTAINABILITY
}

\author{
Bina Agarwal \\ Professor of Economics, \\ Institute of Economic Growth \\ University Enclave, Delhi-110007, India \\ Email:bina@ieg.ernet.in
}

October 2002

This is a substantially revised version of the paper presented at the workshop on Inequality, Collective Action and Environmental Sustainability, Santa Fe Institute, 21-23 Sept 2001. It contains analysis of new data not available at the time of the workshop. This version is forthcoming in a book of the same title, edited by Jean-Marie Baland, Samuel Bowles and Pranab Bardhan, New York: Russell Sage, 2003. I am grateful to the workshop participants for their responses, and to Jean-Marie Baland for his subsequent suggestions. 


\begin{abstract}
This paper examines the effects of gender inequality on prospects of cooperation and environmental sustainability. Gender inequality is a form of inequality that is interactive with but distinct from other forms of economic and social inequalities. It dwells not only outside the household but also centrally within it. It stems not only from pre-existing differences in economic endowments between women and men, but also from preexisting gendered social norms and social perceptions, that is, the inequality is also ideologically embedded. And it not only pre-exists in the noted forms, but can also arise from newly-defined rules and procedures that structure the functioning of the governance institution itself. All three dimensions of gender inequality can impinge on prospects for cooperation and efficient local commons management; and all are largely neglected in collective action literature on the commons. The paper also distinguishes between voluntary and non-voluntary cooperation arguing that cooperation need not always be a voluntary act. Cooperation may appear to exist despite inequalities and conflicts of interest within a community, because it is imposed by some on others through the exercise of social and/or economic power.
\end{abstract}

The paper analyses how these different aspects of gender inequality can impinge on collective action and the form it takes (voluntary or non-voluntary), and the likely outcomes for environmental sustainability. It does so by analyzing the experience of community forest management across India, drawing also on the author's recent field data from western India. In addition, based on the latter, it empirically tests the effects on rule formulation and forest quality of women's greater inclusion in the decision-making process of local commons governance.

Keywords: Gender inequality, cooperation, environmental sustainability, community forestry, India 


\section{INTRODUCTION: SOME DISTINCTIONS}

This paper probes how gender inequality, as a form of inequality that is interactive with but distinct from class, caste, ethnicity, etc, might impinge on prospects of cooperation and environmental sustainability.

Consider first, some distinctions.

\section{(1) Gender inequality}

Gender inequality, in relation to other forms of inequality such as class, caste, or race, has some distinct characteristics. One, gender inequality dwells not only outside the household but also centrally within it. Mainstream economic theory has long treated the household as a unitary entity wherein resources and incomes are pooled, and household members share common interests and preferences (Samuelson, 1956), or an altruistic head ensures equitable allocations of goods and tasks (Becker, 1965, 1981). Most collective action literature is no exception in its assumptions about the household. In studying the effect of inequalities on cooperation in the management of common pool resources (CPRs), for instance, the inequalities recognized stem entirely from householdlevel heterogeneity in say wealth (or class), ethnicity, or caste. Typically, these alone are treated as potentially embodying a conflict of interest,,${ }_{\text {while intra-household inequalities }}$ are ignored.

In recent years, however, virtually every assumption of the unitary model has been challenged effectively on the basis of empirical evidence, including assumptions of shared preferences and interests, pooled incomes, and altruism as the guiding principle of intrahousehold allocations. ${ }^{2}$ Gender, in particular, is noted to be an important signifier of differences in interests and preferences, incomes are not necessarily pooled, and selfinterest resides as much within the home as in the marketplace, with bargaining power affecting the allocation of who gets what and who does what. Among other things, therefore, the household's property status and associated well-being can no longer be taken as automatically defining the property status and well-being of all household members, and especially not as defining women's situation.

Two, gender-inequalities stem not only from pre-existing differences in economic endowments (wealth, income, etc.) between women and men, but also from pre-existing gendered social norms and social perceptions, that is, the inequalities are also ideologically embedded. While norms and perceptions can also impinge on other forms of social inequality such as race and caste, gendered norms and perceptions cut across these social categories and exist in addition to other social inequalities. It is notable

\footnotetext{
${ }^{1}$ Occasionally, there may be a passing reference to gender (e.g. Baland and Platteau, 1996; Verughese and Ostrom, 2001), but without building it into the analysis.

${ }^{2}$ For interesting discussions on problems associated with a unitary conceptualization of the household see, among others, the writings of economists Haddad, Hoddinott and Alderman (1997), Doss (1996), Hart (1993), IDS Bulletin (1991), Katz (1997), Agarwal (1994, 1997a), Lundburg and Pollak (1993), Seiz (2000), and Sen (1990); and anthropologists Guyer and Peters (eds. 1987).
} 
though that most collective action literature, even while discussing the possible impact of social inequality, such as caste or ethnicity, on cooperation, locates the associated conflict of interest essentially in material differences, such as in economic endowments, or in occupational imperatives (e.g. herders vs. agriculturists). The inequalities embedded in social norms or in ideological constructions remain neglected.

Three, gender inequalities not only pre-exist in the noted forms, but can also arise from newly-defined rules and procedures that structure the functioning of the governance institution itself. For instance, the rules that guide the governance of CPR institutions can explicitly or implicitly exclude particular sections of the community, such as women, from its decision-making bodies, or its benefits. Again much of the literature on CPR governance focuses on pre-existing sources of inequalities, and ignores those created or further entrenched by the institution being studied. In other words, inequality is treated as exogenous to institutional functioning, with little recognition of its potential endogeneity.

All three types of gender inequalities can impinge on prospects for cooperation and efficient local commons management.

\section{(2) Voluntary vs non-voluntary cooperation}

A second distinction of relevance in this discussion is that between voluntary and nonvoluntary cooperation (or non-cooperation). The collective action literature essentially assumes cooperation (or its lack) to be a voluntary act: people can make free choices about whether or not to cooperate, based on their economic interests and the benefits they derive (or the costs they incur) from cooperation. This need not always be the case. It is possible, for instance, for people at the lower end of the economic and/or social hierarchy to be forced to cooperate by those at the upper end of the hierarchy. For example, the high-caste landed in an Indian village may threaten to withhold employment or credit from the low-caste landless if they fail to cooperate. Indeed forests were often kept in good condition in feudal times by the power that the feudal lord exercised over the economic and social life of the village (Gold and Gujar 1997; Baland and Platteau, 1996). Similarly, using their power, spouses or community members may threaten women with reputation loss, or even with violence if they break the rules of collective functioning. In

other words, cooperation may appear to exist despite socio-economic inequalities and a conflict of interest between different sections of the community, because it is imposed by some on others through the exercise of social and/or economic power. Here people might follow the rules out of coercion rather than consent, even when their costs from cooperation outweigh their benefits: these would be termed cases of non-voluntary cooperation.

Of course sanctions against those who break the rules (including extra-economic ones such as public reprimand) are often a part of the normal repertoire of rules in institutions governing the local commons (see e.g. McKean, 1986; Baland and Platteau, 1996). But the difference here lies in the unequal and asymmetrical ways in which these penalties might be applied to particular sections of the population, predicated on the power 


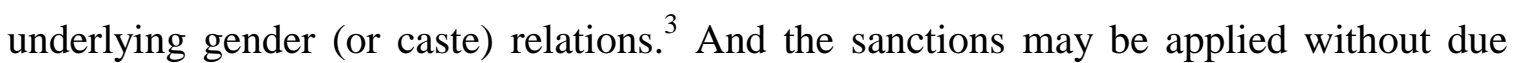
process. Often such sanctions need not even be applied explicitly; they may merely loom large as an unspoken threat, especially in gender relations within the family.

Finally, the sub-distinction non-voluntary non-cooperation also has a place in this discussion. For instance, as elaborated further below, some sections of the community may be excluded from participating in the activities of local institutions because of social norms. A case in point would be strict female seclusion norms which prevent women from joining a forest protection patrol or from attending village meetings even when they would like to contribute to the effort. In other words their non-cooperation (not joining the activity) would be non-voluntary.

The recognition of non-voluntary cooperation (or non-cooperation) is important not only for challenging simplistic assumptions about the nature of cooperation and of inequality, and the presumed relationship between the two that is dominating a burgeoning literature, but also for revealing the hidden costs and conflict of interests that could underlie the achievement of a well-preserved commons. These hidden facets are important to understand both in themselves and because they could reduce potential efficiency gains and even sustainability in the long run.

How might these different aspects of gender inequality impinge on the possibility of collective action and the form it takes (voluntary or non-voluntary)? And what would be the likely outcomes for environmental sustainability? This paper analyses these effects in the context of local institutions for the management of forests in India.

Section II below briefly provides the empirical context of the discussion. Section III elaborates on the nature of gender inequalities relevant to local commons governance in general and forest management in particular. Section IV analyses the implications of these inequalities on women's ability and incentive to cooperate voluntarily in forest management and outlines why we might expect women's cooperation to be in large part non-voluntary. Section V focuses on the likely effects of women's forms of cooperation (or non-cooperation) on the state of the forest. Sections IV and V also pull together empirical evidence which establishes that institutionally created gender inequalities cannot be justified on grounds of efficiency; and further that forest quality could improve with women's greater inclusion in CPR decision-making. Section VI contains concluding comments.

\section{THE CONTEXT}

Rural community forestry groups (CFGs) are amongst the fastest growing forms of collective action in South Asia. In India, these CFGs include: (i) groups formed under the

\footnotetext{
${ }^{3}$ In McKean's (1986) study of village Japan, for instance, such sanctions were meant to be applied uniformly to all community members, although she does not say if this was also the case across the genders.
} 
State-initiated Joint Forest Management (JFM) program launched in 1990, in which villagers and the government share the responsibility and benefits of regenerating degraded local forests; (ii) self-initiated groups, started autonomously by a village council, youth club or village elder and concentrated mainly in the eastern states of Bihar and Orissa; and (iii) groups with a mixed history, such as the van panchayats (forest councils) of the Uttar Pradesh (UP) hills (now in Uttaranchal state) initiated by the British in the 1930s. Some of them have survived or been revived by NGOs. JFM groups are the most widespread, both geographically and in terms of forest area. So far, virtually all Indian states have passed JFM resolutions which allow participating villagers access to most non-timber forest products and to $25-50 \%$ (varying by state) of any mature timber harvested. Today, there are an estimated 36,000 JFM groups, covering 10.2 million hectares (mha) or $13.3 \%$ of the $76.5 \mathrm{mha}$ administratively recorded as forest land (Bahuguna, 2000). ${ }^{-1}$ In addition, there would be a few thousand groups of the other types. NGOs can act as catalysts or intermediaries in group formation and functioning.

In 1998-99 I visited some community forestry sites across five states of India (Gujarat, Karnataka, Madhya Pradesh, Orissa, and the UP hills). Information was obtained mostly through unstructured interviews with villagers, at times conducted with women and men in separate groups, at other times jointly, in addition to individual interviews with key informants, especially office bearers in the executive committees of the CFGs. In addition, in the winters of 2000-01 and 2001-02, systematic data were collected for a sample of villages in three districts of Gujarat. This paper is based largely on my 1998-99 fieldwork, supplemented by some early results from the 2000-02 fieldwork and by existing case studies.

It needs mention here that forests and village commons have always been important sources of supplementary livelihoods and basic necessities for rural households in South Asia. These common pool resources have provided firewood, fodder, small timber, and various non-timber products. Especially for the poor and women who own little private land, they have contributed critically to survival. In India's semi-arid regions in the 1980s, the landless and landpoor procured over $90 \%$ of their firewood and satisfied 69$89 \%$ of their grazing needs from the commons (Jodha, 1986). In that period, firewood alone provided $65-67 \%$ of total domestic energy in the hills and desert areas of India (Agarwal, 1987). This situation was found to have remained largely unchanged even in the early 1990s. Firewood was then still the single most important source (and for many the only source) of rural domestic energy in South Asia, and was still largely gathered, not bought. In 1992-93, for instance, in most states of India over 80\% of rural households used some firewood as domestic fuel, and in all states at least $45 \%$ of the households did so. Moreover, taking an all-India average, only about $15 \%$ of the firewood so used was purchased (Natrajan, 1995).

This continued dependence of villagers on CPRs for daily essentials, at the time when JFM were launched in India, is a critical element in understanding how gender inequality plays out in the context of local commons governance.

\footnotetext{
${ }^{4}$ This figure is different from the approximately 63.3 mha under forest cover as shown by satellite data.
} 


\section{FORMS OF GENDER INEQUALITY}

In this discussion, we particularly need to consider two categories of gender inequalities: (1) pre-existing inequalities in private property resources (such as land and income); and in gendered social norms and perceptions; (2) institutionally created inequalities embedded in the rules and procedures that govern the CFG itself. This section spells out the nature of these inequalities.

\section{(1) Preexisting gender inequalities}

\section{(i) Inequalities in access to private property resources (PPRs):}

Men and women differ in their access to private property and to income-earning opportunities. Typically, women neither own nor directly control arable land (which, apart from crop cultivation, can be an important private source of supplementary products such as firewood, crop waste for fuel, and fodder). 5 They also have lesser access than men to employment and other sources of income (through which they might buy fuel and fodder). Given women's primary responsibility for fuel and fodder this becomes a particular constraint. Women in landless households or in female-headed households (which are more poverty prone) are placed at an obvious disadvantage. But even in male-headed households with land, although women can claim some advantage from the family's endowments in fulfilling their responsibilities, there is no guarantee of access to male-controlled income for purchasing firewood or fodder, or to family land for growing these items. [This would not even be recognized as an issue within a unitary view of the household, but within a bargaining framework all such claims are realistically recognized as subject to negotiation, with women usually operating from a weaker bargaining position. 6 . In general, therefore, gender inequalities in access to PPRs create gender differences in dependence on CPRs across most wealth and asset groups, even if in varying degree.

\section{(ii) Gendered social norms:}

The collective action literature has typically emphasized the enabling and positive side of social norms; but most gendered social norms have a "dark side" which constitutes a significant source of inequality. It needs emphasis that social norms usually constitute not just a "difference" but an inequality. They permeate virtually every sphere of activity: they define what tasks men and women should perform, how they should interact in public, and so on. Consider the most significant ones in the present context.

One, the gender division of labor is both a source of inequality in terms of say the hours of daily work undertaken by men and women, and a source of difference in interest and dependence on the CPR. The more rigid the division of labor the more the conflict of interest this can create. In rural South Asia, typically women work longer hours than

\footnotetext{
${ }^{5}$ Agarwal (1994).

${ }^{6}$ For elaboration on the issue bargaining and gender relations and the factors that might affect women's bargaining power within and outside the home, see Agarwal (1997a).

${ }^{7}$ See e.g. Baland and Platteau (1996); Sethi and Somanathan (2001).
} 
men, $;$ and there is a fairly rigid division of task responsibility. Women, for instance, are largely responsible for cooking and cattlecare and for gathering fuel and fodder, and men for making agricultural implements and for house repair. In relation to the commons, therefore, women are especially concerned with firewood and fodder availability and men with small timber availability. Firewood and fodder, however, are daily needs, which create a persistent pressure on women, while small timber is an occasional need.

Two, in general, village spaces in which men congregate (such as tea stalls and the market place) are spaces that women of "good character" are expected to avoid (Agarwal, 1994). The restriction is somewhat less for older women, but never entirely absent. These notions are often carried over to formal village meetings. A fear of reputation loss or family reprimand, or because they have internalized these norms, restrict women's mobility and their interaction in public decision-making bodies.

Three, there are female behavioral norms. The social strictures on women's visibility, mobility, and behavior, whether internalized by women or imposed on them by threat of gossip, reprimand, even violence, impinge directly on their autonomy and ability to participate effectively in CFGs dominated by men. Female seclusion norms are the most obviously restricting, but the more widespread behavioral norms are almost as pernicious. They create a range of social hierarchies which affect women's voice in private and public, in both obvious and subtle ways.

For instance, in public meetings (such as the general body meetings of CFGs), such norms often require women to sit on the floor while husbands and older village men sit on cots or chairs. Even where everyone sits on a level, often women (including executive committee members) tend to sit at the back or on one side where they are less visible. This makes them less effective in raising their concerns, while the issues raised by the more prominently seated men receive priority. Moreover, the presence of senior male family members makes women hesitant in attending meetings, or speaking up at them, or publicly opposing the men. The hierarchy that marks respectful family behavior also tends to define community interactions. ${ }^{9}$

\section{(iii) Gendered Perceptions:}

Male perceptions about women's appropriate roles and abilities are often at variance with women's real abilities. This serves as an additional source of inequality. Women are usually perceived as being less capable than men, or their participation in public is considered inappropriate or unnecessary. Some typical responses from CFGs are: "Women can't make any helpful suggestions", or that "Women are illiterate, what can they tell you?" In fact, women's illiteracy is commonly underlined to justify a disdain for their opinions, although not infrequently the men expressing such views are themselves unlettered.

\footnotetext{
${ }^{8}$ See e.g. Acharya and Bennett (1981); Akram-Lodhi (1996); Saxena et al. (1995); and Sen (1988).

${ }^{9}$ My fieldwork, 1998-99 and 2000-01; see also, Raju (1997).
} 


\section{(2) Created Inequalities: Gender in Institutional Functioning}

Apart from pre-existing gender inequalities (both material and ideological) there can also be inequalities built into the structure of the governing institution, in particular in its rules and procedures, which can exclude women (in addition to the gender exclusionary effects of social norms), and can make for a highly gender unequal sharing of costs and benefits.

\section{(i) Rules of membership:}

The State-initiated CFGs broadly have a two-tier organizational structure: a general body (GB) which can potentially draw members from the whole village and an executive committee (EC) of some 9-15 persons. The GB is expected to meet once or twice a year and the EC about once a month, although few CFGs are so regular. Both bodies, interactively, define the rules for forest use, the penalties for abuse, and how the forest should be protected (e.g, guards, patrol groups, etc.), the benefit distributed and conflicts resolved. Those with voice and influence in the GB and EC thus determine how the institution functions, and who gains or loses from it.

The eligibility criteria for membership in the JFM general body and EC vary by state. Today eight of the $22 \mathrm{JFM}$ states for which there is information allow GB membership to only one person per household. This is inevitably the male household head. In 8 others (some due to rule amendments), both spouses, or one man and one woman, can be members (Agarwal, 2001). But this still excludes other household adults. Also where the woman automatically becomes a member by virtue of her husband being a member (as in West Bengal), it is he who is seen as the primary member. In only three states (Gujarat, Madhya Pradesh and Haryana) can all village adults become members. In the self-initiated autonomous groups, the situation is worse than under JFM, since these have replicated the customary exclusion of women from village decision-making bodies.

In the ECs within the JFM program the rules are more women inclusive in nominal terms, since recent rule amendments in many states mandate a minimum of 2 or 3 to one-third women. But without a notable presence of women in the GB, or being selected by other women as their representatives, women brought into the EC to satisfy the mandatory requirements are less likely to be active or effective.

\section{(ii) Rules of closure}

Rules of forest closure can vary from a total ban on entry of both humans and animals, to restricted opening that allows the collection of specified products such as firewood and fodder and other non-timber forest products on certain days or seasons annually, to open access for some products throughout the year with a ban on others.

In most CFGs, across the board, timber and greenwood cutting is banned, although some allow highly restricted cutting of small timber for agricultural implements with permission from the EC. But CFGs vary in their rules for firewood and fodder collection and for grazing. Typically, when protection starts most villages start with the most rigid 
rules - banning all entry. As the forests regenerate, a less rigid closure regime could be expected. But in most cases this has not happened, even several years into protection. At best some have moved from a total ban to opening up for a few days annually. As discussed further below, these closures place a disproportionate burden on women, given their daily responsibility for procuring cooking fuel and for cattlecare. The more rigid the rules are, the greater is the burden.

\section{(iii) Rules for benefit sharing}

Benefit sharing has a two-fold component, one is linked to the rules governing what can be extracted from the forest and how much, and the other to the method of distributing what is extracted. There can be gender inequities embedded in both components. For a start, entitlements are linked to membership (which usually needs paying a membership fee and/or contributing to protection by patrolling or helping to pay a guard's wages). Typically non-member households are excluded from benefits. These households usually tend to be poor and so are less able to contribute towards the guard's pay or to patrolling (if men migrate out for work and women are restricted by social norms), with the exclusion disproportionately affecting women. Even for the members, the equity effects depend on the method of distribution. Strict closure, as noted, affects the poorest women the most. But where the forest is opened for a few days annually for firewood or fodder collection, some CFGs allow collection to any number of family members, others to a fixed number of family members, and yet others centralize the collection and distribute an equal number of bundles per family. While this last method ensures equality, in the first two methods, de facto female-headed households with few family members to help them are the most disadvantaged.

Gender disadvantage can also arise in regions where the forest produce is periodically sold. The money so obtained is in rare cases distributed, but only on the basis of one share per household even when both spouses are members. Typically it is put into a collective fund which the EC largely controls, and the use of which it decides either on its own, or (sometimes) in consultation with the GB. Either way women tend to have little say in the use of funds.

How do these noted inequalities - pre-existing and institutionally created - affect women's ability and incentive to cooperate voluntarily?

\section{IMPLICATIONS FOR WOMEN'S COOPERATION}

Cooperation in group functioning could be judged in at least two ways: one, the extent of participation in CFG activities (protection, decision-making, etc), and two rule compliance. Ideally both indicators should be used, rule violation being especially important since it can impinge directly on resource sustainability. However, most studies only take activity participation as an indicator. ${ }^{10}$ Certainly it is easier to measure participation than to

\footnotetext{
${ }^{10}$ See e.g. Verughese and Ostrom (2001); Molinas (1999).
} 
measure rule compliance, since few will admit to breaking the rules, and not every violation is recorded.

Moreover, as noted, cooperation (or non-cooperation) can be either voluntary or nonvoluntary. Again, it is not easy to capture the voluntariness of an action, especially where power relations are involved. Nevertheless qualitative assessments are possible, especially from what people themselves are willing to reveal, or from their actions when particular constraints are removed. Complaining (about the rules for closure, benefit distribution, and so on) could be one indicator of non-voluntary cooperation.

The noted gender inequalities can negatively affect voluntary cooperation on women's part by impinging on both their ability to cooperate and their incentive to do so, the former by affecting women's participation in decision-making, protection work, and so on; the latter by limiting women's options and imposing higher costs and providing lower benefits to them from forest closure.

Table 1 traces the potential effects of gender inequalities that we might expect first on women's ability and incentive to cooperate and then on the nature of cooperation (voluntary or non-voluntary).

\section{(1) Ability to cooperate voluntarily}

(i) Lower participation in CFG management, especially rule-making:

Virtually all the noted gender inequalities obstruct women from participating on equal terms with men in CFG management. For a start, the rules of membership in most states effectively exclude women from full membership, by allowing entry to only one person per household, or by recognizing women only as secondary members, or by excluding women other than spouses. The typical pattern in most CFGs is thus low female participation at all levels. In nominal terms, women generally constitute less than $10-15 \%$ of the general bodies in most JFM groups; ${ }^{12}$ Even in states such as Gujarat which have the most liberal rules and all adults can be members, the percent of women in the GB is typically small; and even where NGOs are active it seldom reaches half (see.e.g. Tables 2 and 4 further below, relating to Panchamahals district, Gujarat where a local NGO is active). The self-initiated groups and van panchayats tend to have even lesser female involvement. ${ }^{13}$ A study of 50 van panchayats found that only 9 had any women (Tata Energy Research Institute, 1995).

\footnotetext{
${ }^{11}$ Admittedly, this is not a fully robust indicator, since people can complain about rules even while breaking them, so that complaining could coexist with non-cooperation.

${ }^{12}$ Roy et al (1992), Guhathakurta and Bhatia (1992) and Narain (1994); also my fieldvisits 1998-99.

${ }^{13}$ For the self-initiated groups see, Kant et al. (1991), and Singh and Kumar (1993), and for van panchayats see Sharma and Sinha (1993), and Tata Energy Research Institute (1995). My fieldvisits in 1998-99 covering both kinds of groups also indicates this.
} 
TABLE 1: IMPLICATIONS OF GENDER INEQUALITY

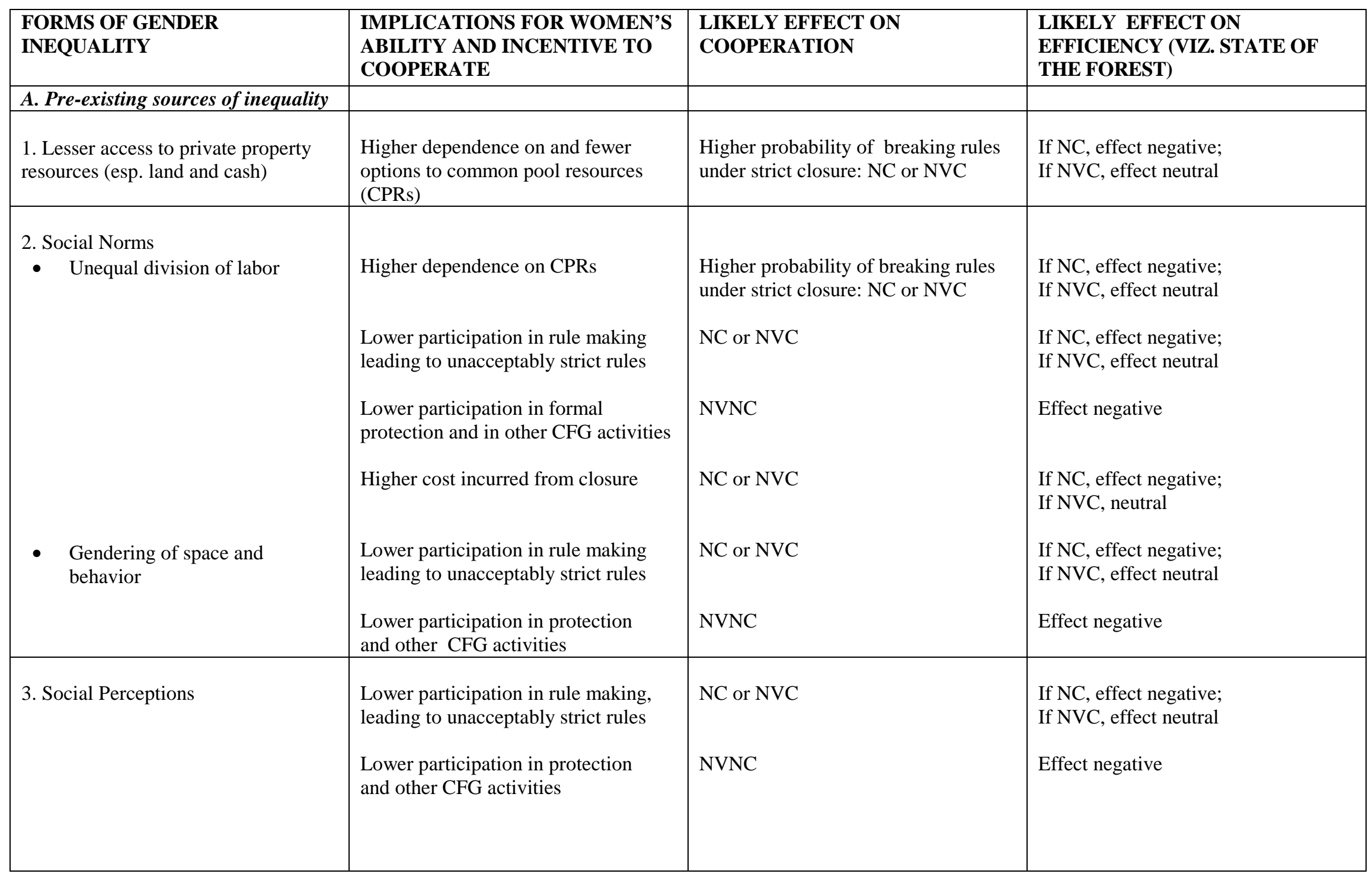




\begin{tabular}{|l|l|l|l|}
\hline B. Institutional sources of inequality & & & \\
\hline 1. Restricted rules of membership & Low participation in decision-making & NC or NVNC & $\begin{array}{l}\text { If NC, effect negative; } \\
\text { If NVNC, effect negative }\end{array}$ \\
\hline 2. Conservative rules of closure & Higher cost from closure & NC or NVC & $\begin{array}{l}\text { If NC, effect negative; } \\
\text { If NVC, effect neutral }\end{array}$ \\
\hline 3. Unequal rules of benefit sharing & Lower benefits from closure & $\begin{array}{l}\text { Less incentive to cooperate: NC or } \\
\text { NVC }\end{array}$ & $\begin{array}{l}\text { If NC, effect negative; } \\
\text { If NVC, effect neutral }\end{array}$ \\
\hline
\end{tabular}

$\mathrm{NC}=$ Non-cooperation $; \mathrm{NVC}=$ Non-voluntary cooperation; $\mathrm{NVNC}=$ Non-voluntary Non-cooperation 
Women are again poorly represented in the ECs, although there is some variation by context. In West Bengal, a study of 20 CFGs found that $60 \%$ had no women, and only $8 \%$ of the 180 EC members were women (Sarin, 1998). But in a number of other states, including Gujarat, there has been some change in recent years since it is now mandatory to include at least two women. In nominal terms therefore at least two get included.

There are of course also some examples of all-women CFGs or mixed CFGs with a high female presence, usually catalyzed by a local NGO, forest official, or donor, or induced by high male outmigration. But these are far from typical. Unfortunately there are no comprehensive figures on this for India, but the 1005 JFM groups for which I collected data through the Madhya Pradesh forest department had no all-women's groups; and of the 1489 self-initiated groups surveyed in Orissa by a network of NGOs only $0.5 \%$ were allwomen.

Within the typical male-dominant mixed CFGs, women are usually ill-informed about meeting dates, and receive limited or no information about what is discussed at meetings. Characteristically, across all the regions women complain:

Typically men don't tell their wives what happens in meetings. Even if there is a dispute about something, they don't tell us; nor do they volunteer information about other matters (women to author, Kheidipada village, Gujarat, 1999).

The men seldom inform us of discussions in meetings. When we ask them they say: 'why do you want to know?' (women to author, Jamai village, Madhya Pradesh, 1999).

Hence accurate information about rules, procedures, or other aspects of forest management, does not always reach the women (my fieldvisits, 1998-99, 2000-02). Similarly, male forest officials seldom consult women or seek their feedback on micro-plans for forest development. Some hear about the plans through their husbands, others not at all (Guhathakurta and Bhatia, 1992). In regions of high male out-migration these communication problems can prove especially acute.

Where women are GB or EC members, usually only a small percentage attend meetings. Table 2, based on data I collected in January 2002 from records of GB and EC meetings from 8 villages in Panchmahals district, Gujarat, is illustrative. To begin with, the table shows a noticeable gap between women's nominal membership and their attendance at meetings in 6 of the 8 villages. While in three of these villages (Asundriya, Golanpur and Kotha) women's membership itself is low, in three others (Dehloch, Falwa and Panchmua) nominal membership is relatively high but attendance is very low. Hence in Dehloch where women nominally constitute $46 \%$ of the GB and $36 \%$ of the EC, in only 1 out of 16 meetings spread over 8 years did women's presence exceed one-third of those attending. ${ }^{14}$ Falwa's record is very similar. The exception is Charada where $60 \%$ of the meetings had more than one-third women attending, largely because the local NGO's

\footnotetext{
${ }^{14}$ There were a few more meetings during this period for which the gender breakup of those attending was not recorded.
} 
staff in that area actively encouraged women's self-help groups (SHG) in the village to also join the CFGs. Hence in Charada, of the 27 women in the GB (out of $51 \mathrm{~GB}$ members) 23 belonged to some form of savings or health group. The minutes of Charada's meetings, however, indicate that most meetings focused on emphasizing to those present that they should take only non-timber species from the forest, rather than soliciting their opinions on significant decisions. Overall, aggregating the 8 villages, women's attendance was low: out of 52 meetings, $88.5 \%$ of the meetings had less than one-third women among those attending. About a quarter of the meetings had no women; and half the meetings have under $15 \%$ or no women.

\section{TABLE 2: CFG MEMBERSHIP AND ATTENDANCE IN MEETINGS BY GENDER: PANCHMAHALS DISTRICT, GUJARAT}

\begin{tabular}{|c|c|c|c|c|c|c|c|c|c|}
\hline \multirow[t]{2}{*}{$\begin{array}{l}\text { Villages } \\
\text { (Gujarat) }\end{array}$} & \multicolumn{2}{|c|}{ Women members* } & \multicolumn{2}{|c|}{ Meetings } & \multicolumn{5}{|c|}{$\begin{array}{l}\text { Attendance at Meetings: } \\
\text { women as } \% \text { of total attendees }\end{array}$} \\
\hline & $\%$ in GB & $\%$ in $\mathrm{EC}$ & Period & No & $\mathbf{0}$ & $>0-15$ & $>15-25$ & $>25-33$ & $>33$ \\
\hline Asundriya & 6.0 & 18.2 & 1999-01 & 5 & 4 & 1 & - & - & - \\
\hline Charada & 52.9 & 27.3 & 2000-01 & 5 & - & 1 & - & 1 & 3 \\
\hline Dehloch & 45.8 & 36.4 & 1992-00 & 16 & 2 & 5 & 6 & 2 & 1 \\
\hline Falwa & 45.1 & 36.4 & 1997-01 & 9 & 3 & - & 5 & - & 1 \\
\hline Golanpur & 15.6 & 18.2 & 1999 & 1 & 1 & - & - & - & - \\
\hline Kotha & 1.5 & 18.2 & $2000-02$ & 8 & 2 & 5 & 1 & - & - \\
\hline Manchod & 21.9 & 27.3 & 1999-02 & 7 & - & 2 & 2 & 2 & 1 \\
\hline Panchmua & 21.9 & 36.4 & 2001 & 1 & - & - & 1 & - & - \\
\hline Total & & & & 52 & 12 & 14 & 15 & 5 & 6 \\
\hline \% of total & & & & & 23.1 & 26.9 & 28.8 & 9.6 & 11.5 \\
\hline
\end{tabular}

Note: * GB members are taken here as those listed in the registration letter or whose names have been submitted in the registration application as having formally paid Rs. 11 membership fee. Often, however, not all those so registered, especially the women, have necessarily sought membership. Some have agreed to or been persuaded to pay the fee to help the village fulfil the registration requirements. In effective terms, those considered members in these villages are households who participate actively in protection by contributing to patrolling or the guard's pay. The numbers of such households fluctuate, but usually far exceed those formally registered.

The gender division of labour and social norms are among the important factors underlying women's low turn out at meetings:

If we were to attend meetings, the men will say, oh you haven't cooked my meal on time. What happened to my tea? ... Why haven't you fed the cattle? Men make a big 
fuss about every small thing; so we are afraid when it comes to going out of the house for something that's not considered work (women to author's research team, Panchmua village, Gujarat, 2001).

The meetings are considered for men only. Women are never called. The men attend and their opinions or consent are taken as representative of the whole family - it's understood (woman in a van panchayat village, UP hills, cited in Britt, 1993: 148).

Rural women and men can't sit together. But we convey our decisions to them (man to author, Chattipur village, Orissa, 1998).

Sometimes, when asked directly, men admit that women's presence in meetings would help, but the most frequently given reason is: "because women are the ones who cut the wood. If they came to meetings they would understand the need to protect the forests". As noted, this is also reflected in the minutes (where available) of the meetings in Table 2 where the concern was largely to convey a message of restraint about the species women could take from the forest. There was rarely recognition that women could contribute to rule making or to improved forest management.

If women do attend CFG meetings (in Gujarat or elsewhere) they seldom speak up, although the chances of them feeling emboldened to do so increase if they are present in relatively large numbers. When they do speak, however, their opinions typically receive little weight.

Women cannot speak in front of elderly male relatives, and they have to observe purdah (women to author's research team, Bambri village, Gujarat, 2001).

People don't like it when we speak... They think women are becoming very smart (women to author's research team, Kotha village, Gujarat, 2001).

I went to three or four meetings.... No one ever listened to my suggestions... They were uninterested (women in UP hills, cited in Britt, 1993: 146).

Having a voice in the $\mathrm{EC}$ is important since this is a forum for discussions and decisions on most aspects of CFG functioning. As matters stand, they are not party to many crucial decisions. An analysis of JFM decision-making in five Gujarat villages revealed that all major decisions on forest protection, use, distribution of wood and grass, and future planning, were taken by men (Joshi, 1998).

This is not to suggest that women's nominal presence does not count. Even if women are silent it provides them information about what is happening in the CFG which they can share with other women, and it improves their sense of involvement. It is thus a necessary first step. And as the regression results presented further below show, even this can have a positive effect on the state of the forest. But for effective participation women also need to have a greater say in the decisions made. 


\section{(ii) Lower participation in CFG activities}

Inequalities in social norms, social perceptions, and institutional procedures also interact to restrict women's participation in other CFG activities. For instance, protection of the bounded area is a central CFG activity. In formal terms, this is usually done by employing a guard, with CFG members contributing the wage in kind or cash, or by forming a patrol group from among the member households. A male guard or an all-male patrol is typical: these two methods respectively characterized $37 \%$ and $22 \%$ of the 73 sites I visited in 1998-99. Female guards were rare, and only a small percentage of patrols had both sexes or women alone. Occasionally, there are shifts from all-men to all-women patrols, and vice versa (Agarwal, 2001).

The gender division of labor and women's higher work burden puts greater constraints on their time; fear of physical assault restricts their ability to undertake night patrolling; and in some areas where gender segregation is high, mixed patrolling is socially unacceptable.

Similarly social norms and the perception that women have little to contribute, exclude women from many other CFG activities. Women, for instance, are seldom part of teams taken on "exposure" visits to learn from other CFGs or given training in silviculture practices.

\section{(2) Incentive to cooperate voluntarily}

\section{(i) Fewer alternatives to CPRs}

Two types of gender inequalities, in particular, lead to women's greater dependence on the commons, and limit their options: one, lesser personal ownership of PPRs with no guaranteed voice in how household-level PPRs are to be used; and two, the unequal and relatively rigid gender division of labor. The implications of the first are obvious. The second places the burden of procuring items such as domestic cooking fuel mainly on women. And in the absence of well-developed rural markets for firewood (the preferred cooking fuel), this item has largely to be gathered, or substituted by equally littlemonetized fuels such as crop waste or dung. Hence even if women had the means to purchase these, in many regions they lack the option. [In rural India, 92\% of domestic energy comes from firewood, dung and crop residues, and only around 15\%, 6\% and 3\% of each respectively are purchased: Natrajan, 1995.] On the one hand this dependency on CPRs gives women a stake in the regeneration of the resource, on the other hand it makes immediate availability imperative and reduces their incentive to cooperate within strict closure regimes.

\section{(ii) Higher costs of forest closure:}

The costs of forest protection are broadly of two types: those associated with protection and management and those associated with forgoing forest use due to closure. The former would include costs such as membership fees, the forest guard's pay, the opportunity cost of patrolling time, and so on -- costs largely borne by men. The latter would include the 
opportunity cost of time spent in finding alternative sites for essential items such as firewood and fodder, other costs (identified below) associated with firewood shortages, the loss of livelihoods based on non-timber forest products, and so on. Such costs fall largely on women. In overall terms too, the costs tend to be higher on women.

For instance, in scarcity areas typically the forest is totally closed for a start. If the area was highly degraded anyway, this need cause no extra hardship, but where earlier women could meet at least part of their fuel and fodder needs from the protected area, they were now forced to seek other options, including searching for alternative sites in the neighborhood and increasingly substituting inferior fuels such as crop waste and dung for firewood. In the early years of JFM, Sarin (1995) found that after closure, in some villages of Gujarat and West Bengal journeying to neighboring sites increased women's collection time and distances traveled for a headload of firewood several-fold: from 1-2 hours to 4-5 hours, and from half a $\mathrm{km}$ to 8-9. Even this option was foreclosed when the neighbours too began to protect. But some women still felt compelled to enter protected tracts, with the risk of being caught and penalised by a patrol group or guard. Hence the initial cost of strict closure was borne disproportionately by women. But what about changes over time, given that strict closure might be needed in some of the CFGs to ensure vegetation recovery?

Over time, with forest regeneration we would have expected a shift to less rigid regimes that allowed extractions to ease these shortages. This has hardly happened. In a majority of cases conservative regimes continue. Of the 73 CFGs I visited in India in 1998-99, 67 had firewood available. Of these $34(50.7 \%)$ had a ban on firewood collection, wherein 20 did not open the forest at all and 14 opened it for a few days annually for drywood collection, and infrequently for cutback and cleaning operations. The remaining 33 CFGs allowed some collection on a continuing basis, but usually only of fallen twigs and branches and sometimes only of certain types of non-timber species.

Even after years of protection, women thus reported a persistence of firewood shortages in the majority of villages across five states that I visited in 1998-99 (for a tabulation, see Agarwal, 2001). In some cases, acute shortages were reported. The exceptions were regions that already had relatively good forests when protection started, as in parts of Madhya Pradesh and Orissa.

Some characteristic responses in scarce regions are given below:

We go in the morning and only return in the evening. Since the end of the rainy season, we have been going every day. I go myself and so does my daughter. Earlier too there was a shortage but not as acute (woman EC member to author, Kangod village, Karnataka, 1998).

How will we cook if we don't get wood from the forest? What do they expect us to do? (Women to author's research team, Panchmua village, Gujarat, 2001).

\footnotetext{
${ }^{15}$ For a tabular listing of potential costs and benefits by gender, see Agarwal (2001)
} 
Usually women from both middle and poor peasant households report firewood shortages, since even the former seldom purchase firewood or have enough private trees for selfsufficiency. Where possible, women have substituted other fuels: a few could switch to biogas, but for most households gas or kerosene were not real options, hence they have to use inferior fuels such as dung, crop waste, even dry leaves. These fuels need more time to ignite and tending to keep alight, thus adding to cooking time; the additional smoke has negative health effects; and in some areas women economize on fuel by forgoing a winter fire for space heating (even in subzero temperatures), by not heating bath water in winter or heating it only for husbands, and so on. In terms of smoke, estimates by Smith et al. (1983) suggest that even when cooking with firewood on an open stove, the benzo(a) pyrene inhaled daily is equivalent to smoking 20 packs of cigarettes. This increases women's risk of cancer, tuberculosis, and various respiratory ailments (CSE, 2001). Dung and crop waste are much worse offenders on this count than firewood. And even in terms of firewood, some of the species women are allowed to collect generate more smoke than the so-called timber species which they are not allowed to touch.

Women of landless or landpoor households, however, lack even the gption of crop waste or dung, since they have no land or trees of their own and few cattle. ${ }^{16}$ Indeed, closures have forced many poorer families to reduce their animal stocks (due to fodder shortages) which also reduces dung supply. As a poor woman in Khut village (UP hills) told me: "We don't know in the morning if we will be able to cook at night".

Is this cost unavoidable - a necessary price to pay for sustainable forest regeneration? Table 3 dramatically illustrates otherwise. In principle, for those dependent mainly on the commons, acute firewood shortages can arise both from inadequate availability of woody biomass in the protected forest and from restricted access to what is available. In practice, as Table 3 shows, the acuteness of the shortages has much to do with restricted access. The table is based on studies undertaken by a network of ecologists, social scientists and NGOs (and pulled together by Ravindranath et al, 2000). The studies provide information on the annual woody biomass regenerated in the protected forests, the annual firewood extraction, and the annual need for firewood in 12 villages (all with CFGs) relating to 3 states. ${ }^{17}$ It is assumed, as a conservative rule of thumb, that $50 \%$ of the annual biomass regenerated per year can be extracted sustainably. [The estimates of annual biomass generated are themselves on the conservative side, since they exclude biomass with a girth of $<10 \mathrm{~cm}$, some of which is used as fuel.]

\footnotetext{
${ }^{16}$ See also Jodha (1986) on differences between landed and landpoor rural households in India, in their dependence on the commons for firewood and fodder.

${ }^{17}$ The studies covered more villages, but those which lacked complete information or had data discrepancies were not included in Table 3 .
} 
TABLE 3: FIREWOOD: SUSTAINABLY EXTRACTABLE, ACTUAL EXTRACTION, AND NEED

\begin{tabular}{|c|c|c|c|c|c|c|c|c|c|c|c|c|}
\hline Village/State & $\begin{array}{l}\text { Forest } \\
\text { area (ha) } \\
\text { protected }\end{array}$ & $\begin{array}{l}\text { Prot } \\
\text { Yrs } \\
\text { (in ' }\end{array}$ & $\begin{array}{l}\text { Form } \\
6)\end{array}$ & \multirow[t]{2}{*}{$\begin{array}{l}\text { Basal } \\
\text { area } \\
\text { (ha) }\end{array}$} & \multirow[t]{2}{*}{$\begin{array}{l}\text { Growing } \\
\text { stock (t/ha) }\end{array}$} & \multirow[t]{2}{*}{$\begin{array}{l}\text { Mean } \\
\text { Annual } \\
\text { Increment } \\
\text { (t/ha/yr) } \\
\end{array}$} & \multirow[t]{2}{*}{$\begin{array}{l}\text { Sustainably } \\
\text { extractable } \\
(\mathrm{t} / \mathrm{yr})\end{array}$} & \multirow[t]{2}{*}{$\begin{array}{l}\text { Actual } \\
\text { extraction } \\
(\mathrm{t} / \mathrm{yr})\end{array}$} & \multirow[t]{2}{*}{$\begin{array}{l}\text { Firewood } \\
\text { need for } \\
\text { village } \\
(\mathrm{t} / \mathrm{yr}) \\
\end{array}$} & \multirow[t]{2}{*}{$\begin{array}{l}\text { Extraction } \\
\text { as } \% \text { of } \\
\text { extractable }\end{array}$} & \multirow[t]{2}{*}{$\begin{array}{l}\text { Extraction } \\
\text { as \% of } \\
\text { need }\end{array}$} & \multirow[t]{2}{*}{$\begin{array}{l}\text { Extractable } \\
\text { as \% of } \\
\text { need }\end{array}$} \\
\hline Gujarat & & & & & & & & & & & & \\
\hline Asundriya & $176 *$ & 8 & $\mathrm{SC}$ & 14.4 & 144.5 & 4.10 & 361 & 35 & 554 & 9.7 & 6.3 & 65.2 \\
\hline Baluji na muada, & 122 & 11 & $\mathrm{SC}$ & 44.9 & 343.4 & 9.75 & 595 & 46 & 511 & 7.7 & 9.0 & 116.0 \\
\hline Garda & 100 & 6 & $\mathrm{M}$ & 1.2 & 58.5 & 1.66 & 83 & 38 & 264 & 45.8 & 14.4 & 31.4 \\
\hline Kunbar & 188 & 4 & $\mathrm{M}$ & 2.0 & 63.7 & 1.81 & 170 & 61 & 603 & 35.9 & 10.1 & 28.2 \\
\hline Rampur & 120 & 4 & $\mathrm{M}$ & 3.0 & 70.2 & 1.99 & 119 & 94 & 185 & 79.0 & 50.8 & 64.3 \\
\hline \multicolumn{13}{|l|}{ Karnataka } \\
\hline Alalli & 73 & 20 & $\mathrm{SC}$ & 13.8 & 140.6 & 3.99 & 146 & 0 & 416 & 0.0 & 0.0 & 35.0 \\
\hline Halakar & 20 & 72 & $\mathrm{LC}$ & 10.5 & 119.1 & 3.38 & 34 & 107 & 521 & 169.8 & 20.5 & 12.1 \\
\hline Hunasar & 120 & 100 & $\mathrm{SC}$ & 33.1 & 266.5 & 7.57 & 454 & 262 & 496 & 57.7 & 52.8 & 91.5 \\
\hline Kugwe & 194 & 100 & $\mathrm{LC}$ & 24.5 & 210.4 & 5.98 & 580 & 209 & 697 & 36.0 & 30.0 & 83.2 \\
\hline \multicolumn{13}{|l|}{ West Bengal } \\
\hline Bhagawatichowk, & 53 & 11 & $\mathrm{SC}$ & 10.5 & 119.1 & 3.38 & 90 & 54 & 176 & 60.0 & 30.7 & 51.1 \\
\hline Kapasgaria & 25 & 5 & $\mathrm{SC}$ & 11.3 & 124.3 & 3.53 & 44 & 8 & 139 & 18.2 & 5.8 & 31.6 \\
\hline Kharikamathani, & 57 & 3 & $\mathrm{LC}$ & 4.0 & 76.7 & 2.18 & 62 & 87 & 161 & 140.3 & 54.0 & 38.5 \\
\hline
\end{tabular}

\section{Basis for calculations (taken from Ravindranath et al, 2000)}

Growing stock $=50.66+($ Basal area $\times 6.52)$. Woody biomass with a girth of $<10 \mathrm{~cm}$ was not included. t/ha $=$ tons per hectare.

Mean Annual Increment $(\mathrm{MAI})=2.84 \%$ of the Growing stock

Sustainably extractable $=($ MAI $x$ forest area $) / 2$

For the 4 Karnataka villages, the case study assumes firewood need to be $1.67 \mathrm{~kg} / \mathrm{capita} / \mathrm{day}$. I have assumed the same for calculating firewood needs for Garda,

Kunbar and Rampur, since information on need was not given in the case study.

\section{Assessments by author from information given in Ravindranath et al (2000)}

$\mathrm{SC}=$ Strict closure: Firewood cutting banned except for a few days per year. In some cases, collection of fallen twigs is, however, allowed all year round.

LC $=$ Lenient Closure: Firewood extraction in the form of twigs and dry branches allowed throughout the year.

$\mathrm{MC}=$ Mixed Closure: A combination of LC and cutback/cleaning operations undertaken for a few days each year or every few years.

* Ravindranath et al. (2000) give a figure of $182 \mathrm{ha}$, but the forest department records show that 175.94 ha is the area registered formally as under protection.

Source: Compiled/calculated from information given in Ravindranath et al (2000). 
In 6 out of the 12 villages, less than $15 \%$ of the estimated firewood needed is being satisfied from the forest, and in none is more than $55 \%$ being satisfied. However, the point of note is that these shortages could be very substantially reduced by extracting much more than is being done. In 10 of the 12 villages extractions are far below even the conservative extractable limit and of the two villages which show over-extraction, in one Kharikamathani - the amount extracted is still below the total biomass produced per year. 18 In three villages extraction is less than $10 \%$ of extractable levels. If these villagers extracted up to the extractable limit set, Baluji na muada could more than satisfy its firewood requirements, and Asundriya and Allali villages could satisfy $65 \%$ and $35 \%$ of their needs respectively. Hence while firewood shortages might still persist, they would be much less acute. Currently these villages satisfy only $6 \%, 9 \%$ and $0 \%$ respectively of their needs. The very low levels of extraction in cases such as these are due to strict closure regimes, enforced without women's acquiescence. In fact even in nominal terms, virtually none of the villages in table 3 has even one woman on its EC.

Now consider Table 4 which is based on data collected by me in 2000-01 and 2002 from 19 villages in Panchamahals district (Gujarat). In most of these 19 villages women report firewood shortages, as indicated by their dependence on inferior substitutes, crop waste and dung; and many report an increase in this dependence with protection. ${ }^{19}$ However, there is some difference between villages with strict closure, that is villages which only allow the cutting of specified (so-called firewood) species for a few days annually, and the villages with somewhat lenient closure which too allow cutting only of specified species, but on a regular basis. In all 9 strict closure villages women report a substantial dependence on inferior fuels, which has grown with closure in several cases, while in 3 of the 9 more lenient villages women report little or no use of inferior fuels and do not complain of firewood shortages.

What explains the difference in closure regimes? Does the presence or absence of women in the GBs and ECs affect closure rules? Table 4 suggests that the nature of protection might be dictated in large part by the number of segments in which the forest is divided (and the associated practical difficulties of strict monitoring), rather than by women's needs or their greater voice in decision-making. This is borne out by the results of the probit analysis presented in Table 5. The dependent variable -- the closure regime -- is binary (strict closure $=1$; lenient closure $=0$ ). The three explanatory variables used are: number of forest segments (FSEG); per cent women in the EC (WEC), and forest area per household (FAHH). We would expect strict closure to be associated negatively with all three. The greater the number of forest segments, the more difficult it is to ensure strict monitoring. The larger the proportion of women in the EC the less strict we would expect closure to be, since women would have an interest in a more lenient regime. And the larger the forest area per household the less incentive would there be to have strict closure and the more difficult would it be to monitor the resource carefully.

\footnotetext{
${ }^{18}$ This could well be the case too in the second over-extracting village, Halaker, given that (as noted) biomass of $<10 \mathrm{~cm}$ was not counted.

${ }^{19}$ This is apart from an overall shortage even of crop waste due to three years of low rainfall.
} 


\section{TABLE 4: DETAILS OF CFG FUNCTIONING IN THE STUDY VILLAGES OF PANCHMAHALS DISTRICT, GUJARAT}

\begin{tabular}{|c|c|c|c|c|c|c|c|c|c|c|c|}
\hline \multirow[t]{2}{*}{$\begin{array}{l}\text { Village } \\
\text { /Regulation }\end{array}$} & \multirow{2}{*}{$\begin{array}{l}\text { HHs } \\
1991 \\
\text { census@ }\end{array}$} & \multicolumn{2}{|c|}{$\begin{array}{l}\text { Forest area } \\
\text { protected (ha) }\end{array}$} & \multirow{2}{*}{$\begin{array}{l}\text { Forest } \\
\text { Seg- } \\
\text { ments* }\end{array}$} & \multicolumn{2}{|l|}{ Forest quality } & \multirow[t]{2}{*}{$\begin{array}{l}\text { Protection } \\
\text { method }\end{array}$} & \multicolumn{2}{|c|}{$\begin{array}{l}\text { Women } \\
\text { members }\end{array}$} & \multicolumn{2}{|l|}{ Fuel use } \\
\hline & & Total & $\begin{array}{l}\text { Per } \\
\mathrm{HH}\end{array}$ & & $\begin{array}{l}\text { Before } \\
\text { Protection } \\
\text { (as reported) }\end{array}$ & $\begin{array}{l}\text { Now@@ } \\
\text { (assessed) } \\
\text { scale 1-5 } \\
\end{array}$ & & $\begin{array}{l}\% \text { in } \\
\mathrm{GB}\end{array}$ & $\begin{array}{l}\% \text { in } \\
\mathrm{EC}\end{array}$ & $\begin{array}{l}\text { Use } \\
\text { Inferior } \\
\text { fuel partly }\end{array}$ & $\begin{array}{l}\text { Women complain of firewood } \\
\text { shortages }\end{array}$ \\
\hline \multicolumn{12}{|c|}{ STRICT FOREST CLOSURE } \\
\hline Asundriya & 105 & 175.94 & 1.68 & 1 & $\mathrm{D}$ & 4.5 & Guards & 6.0 & 18.2 & Yes & Yes (more shortage now) \\
\hline Boria & 660 & 482.25 & 0.73 & 3 & $\mathrm{D}$ & 3.5 & Guards & 10.0 & 18.2 & Yes & Yes \\
\hline Kotha & 161 & 310.03 & 1.92 & 3 & $\mathrm{D}$ & 4.25 & Guard & 1.5 & 18.2 & Yes & Yes (some steal) \\
\hline Mor & 242 & 306.00 & 1.26 & 1 & $\mathrm{D}$ & 4.5 & Guard & 36.4 & 36.4 & Yes & Yes (more shortage now) \\
\hline Dehloch & 281 & 53.25 & 0.19 & 1 & $\mathrm{D}$ & 4.75 & Guard & 45.8 & 36.4 & Yes & Yes (women economize) \\
\hline Falwa & 172 & 199.11 & 1.16 & 2 & $\mathrm{D}$ & 3.25 & Hamlet F & 54.9 & 36.4 & Yes & Yes (some steal) \\
\hline Golanpur** & 145 & 546.00 & 3.77 & 3 & $\mathrm{D}$ & 3.0 & Hamlet I & 15.7 & 18.2 & Yes & Yes \\
\hline Manchod & 233 & 100.00 & 0.43 & 2 & $\mathrm{D}$ & 3.5 & Hamlet F & 21.9 & 27.3 & Yes & Yes (more shortage now) \\
\hline Singalgadh & 147 & 59.18 & 0.40 & 2 & $\mathrm{D}$ & 2.5 & Hamlet I & 9.1 & 18.2 & Yes & Yes (acute shortage now) \\
\hline \multicolumn{12}{|c|}{ LENIENT FOREST CLOSURE } \\
\hline Bambri & 100 & 425.00 & 4.25 & 4 & $\mathrm{D}$ & 3.0 & HH I & 1.8 & 15.4 & No & No \\
\hline Charada & 83 & 241.71 & 2.91 & 5 & $\mathrm{D}$ & 3.0 & Hamlet I & 52.9 & 27.3 & Yes & No (most; but poor Naiks report shortage) \\
\hline Gadh & 66 & 15.27 & 0.23 & 3 & $\mathrm{D}$ & 3.0 & HH I & 0.0 & 18.2 & Yes & Yes (women economize) \\
\hline Kunda & 112 & 433.83 & 3.87 & 4 & $\mathrm{D}$ & 3.0 & HH I & 0.0 & 18.2 & Yes & Yes (more shortage now) \\
\hline Nansalai & 95 & 170.00 & 1.79 & 1 & $\mathrm{D}$ & 3.75 & Hamlet F & 5.7 & 27.3 & No & No \\
\hline Navivasat & 60 & 32.00 & 0.53 & 2 & $\mathrm{D}$ & 3.25 & HH I & NA & 27.3 & No & No \\
\hline Padedi & 249 & 133.83 & 0.54 & 6 & $\mathrm{D}$ & 2.5 & HH I & 1.1 & 18.2 & Yes & Yes (some steal) \\
\hline Panchmua & 153 & 179.97 & 1.18 & 5 & $\mathrm{D}$ & 3.75 & Hamlet I & 21.9 & 36.4 & Yes & Yes (more shortage now) \\
\hline Sattalab & 127 & 150.00 & 1.20 & 3 & $\mathrm{D}$ & 3.5 & $\mathrm{HH} \mathrm{I}$ & 33.3 & 26.7 & Yes & Yes \\
\hline Vandaria & 41 & 52.61 & 1.28 & 2 & $\mathrm{D}$ & 2.5 & $\mathrm{HH} \mathrm{I}$ & 17.6 & 18.2 & Yes & Yes (more shortage now) \\
\hline
\end{tabular}

Notes:

Strict protection: $\quad$ Cutting of all timber species banned throughout the year; cutting of firewood species banned except when forest opened for a few specified days annually to allow such cutting under monitoring; open for fallen twigs and branches through the year except in Asundriya, Dehloch and Singalgadh where this too is banned.

Lenient protection: Cutting of all timber species banned throughout the year. Cutting of firewood species and also collection of fallen twigs and branches allowed throughout the year.

Hamlet I: Hamlet-wise informal protection; Hamlet F: hamlet-wise formal patrolling; HH I: Informal protection by households near forest 
* Segments: $\quad$ Two criteria were used to determine number of forest segments: (i) Non-contiguous forest parts separated by non-forest land or canal, etc. (ii) Number of sides of the village that the forest covers. Hence where it covers 3 sides of the forest, it is counted as 3 segments even if it is contiguous.

** Includes the additional hamlet Hathirani na muada hhs which has been protecting and using part of the forest

$\mathrm{D}=$ degraded

@ Data taken from 1991 census except for Navivasat, for which information was obtained directly from the village since census information was unavailable.

@ @ Assessment of forest in comparative terms on a scale of 0 to 5:

$0=$ totally degraded; $1=$ some growth; $5=$ consistently good in terms of forest density, age (as indicated by girth and height), and overall regeneration. In between are forests which are good in parts but not consistently so.

SOURCE: Author's fieldwork 2000-01, 2002

\section{TABLE 5: FACTORS AFFECTING STRICTNESS OF FOREST CLOSURE: PROBIT RESULTS}

Dependent Variable: CLR

Method: ML - Binary Probit

Sample: 119

Included observations: 19

\begin{tabular}{crrrr}
\hline \hline Variable & Coefficient & Std. Error & z-Statistic & Prob. \\
\hline \hline C & 1.797616 & 1.762546 & 1.019897 & 0.3078 \\
FSEG & $-0.626543^{*}$ & 0.338640 & -1.850175 & 0.0643 \\
WEC & -0.008060 & 0.051736 & -0.155786 & 0.8762 \\
FAHH & -0.015116 & 0.304199 & -0.049692 & 0.9604 \\
\hline \hline Mean dependent var & 0.473684 & S.D. dependent var & 0.512989 \\
Log likelihood & -10.06834 & McFadden R-squared & 0.233966 \\
Restr. log likelihood & -13.14347 & & & \\
LR statistic (3 df) & 6.150262 & & \\
Probability(LR stat) & 0.104524 & & 19 \\
\hline \hline Obs with Dep $=0$ & 10 & Total obs & \\
Obs with Dep $=1$ & 9 & & \\
\hline \hline
\end{tabular}

* Significant at the $10 \%$ level 
As hypothesized, all three coefficients have a negative sign, but only FSEG is statistically significant. ${ }^{20}$ All the villages with strict closure have at most three segments of forest, and even among those with three segments two villages (Boria and Kotha) have a continuous stretch of forest. The villages with more lenient closure mostly have more than three segments and noncontiguous patches. The scatter of the forest also affects the form of protection. All the villages with strict closure employ either guards (where there is a continuous stretch of forest) or a hamletwise form of protection. In the villages with more lenient closure, the forest is typically scattered in several parts and here responsibility for protection usually vests in the households located near a given part, and occasionally with the hamlet as a whole. It is perhaps not surprising that women's presence in the EC in itself does not make a significant difference to the choice of closure regime, given that they have little voice in decisions. At best, from my interviews in these villages, women's complaints about strict closure helped shift some of the villages which earlier allowed no extraction at all to allowing some extraction for a few days annually.

The second major cost that falls disproportionately on women, stems from the common ban on grazing, necessitating households to procure fodder in other ways and to stall-feed animals. Household responses to fodder problems can vary, but women remain in a no-win situation. Poor households, for instance, have been selling off their cattle, which reduces dung availability for both fuel and manure. In households that have kept their cattle but cannot afford to buy fodder, women spend additional time seeking alternative sites, apart from spending time and energy on stallfeeding and stall cleaning. This is also the case among households that have replaced their goats with milch cattle. In parts of Gujarat women report on average an extra workload of 2-3 hours due to stall-feeding alone. Moreover, in some Gujarat villages, where dairy cooperatives have been opened, the cattle numbers have in fact increased, and feeding and washing them has placed severe burdens on the women. The milk so obtained is typically sold and not drunk by the family, and the cash returns from the sale are usually controlled by the men (author's interviews, January 2002).

\section{(iii) Lower benefits from forest closure:}

Given the methods used for distributing the benefits, closure typically brings fewer benefits for women than men. Some of this difference arises from the CFG's distribution rules and some from an interactive effect of the rules with unequal intra-household allocations. Benefits can derive from the distribution of forest products in kind (e.g. firewood, fodder, other non-timber products, timber, etc.); or from the use of collective funds (obtained through membership fees, fines, selling forest produce, compulsory deduction from wages received for any forest work, and so on); or from the distribution of cash benefits (in rare cases). Women benefit directly if the benefits are in kind (e.g. in the form of firewood or fodder), but the extent of benefit depends on the rules of drywood or fodder extraction. As noted above, strict closure regimes have minimized such benefits. Other non-timber products (such as tendu leaves), of which most CFGs allow collection, are seasonal, and while women collect them, men are the one's who usually sell them and control the proceeds.

\footnotetext{
${ }^{20}$ Total forest area was also tested as an explanatory variable but turned out to be insignificant as well.

${ }^{21}$ In their study of a Nepalese village, Thomas-Slater and Bhatt (1994) found that adding stallfed milch cattle restricted women's mobility, lessened or erased their leisure time, and even caused girls to drop out of school.
} 
Community funds are similarly controlled by male-dominant ECs. Women have little say in fund allocations. Data from 29 CFGs across six Indian states that I examined, for instance, showed that most commonly, the funds were put to uses from which women were unlikely to benefit, such as youth club repair, purchasing community utensils, rugs, drums etc. (which the men used or leased out), and travel by EC members (see also, Agarwal, 2001). In some regions, such as Orissa, spending on religious functions and youth clubs was especially common (my fieldwork, 1998).

Would women spend such funds differently if they had more control? While a definitive answer is not possible in the absence of comparable information for women-dominant CFGs or allwomen CFGs, related information from all-women panchayats (village councils) and other women's groups is strongly indicative. Early studies in Madhya Pradesh and Maharashtra, for instance, found all-women panchayats to differ from all-male ones in the priorities they gave to community concerns. Women placed greater emphasis to funding the provision of taps and covered toilets in Madhya Pradesh (Gandhi and Shah, 1991), and to the installation of pumps on village wells, building toilets in low caste hamlets, and filling vacancies for village school teachers in Maharashtra (Gala, 1990). More recent studies reinforce these early observations: women panchayat members and chairpersons are found to pay more attention to solving problems of drinking water, children's education, roads, and electricity supply (CWDS, 1999; UNDP, 2001). At times, women's interventions in mixed panchayats has also led to shifts in priorities. In two Karnataka villages, five women elected representatives disagreed with the men's decision to construct a water tank, pointing out that the villages had adequate water but lacked health facilities, roads and schools, and the funds should be spent on these needs (Narasimhan, 1999). All this suggests that if women control or have a say in CFG funds, the funds are more likely to flow toward community needs and alternative priorities.

Gender-related distributional inequalities in CFGs also stem from the transfer of any cash benefits solely to men (on behalf of the household), or giving the household only one share when both spouses are members. Such transfers assume a common gender interest and deny their possible negative effect on women's incentive to cooperate. In practice, money given to men does not guarantee equal sharing or even any sharing within the family. As found in non-CFG contexts (e.g. Dwyer and Bruce, 1994), here too men have been known to spend a substantial part on gambling, liquor, or personal items. ${ }^{22}$ It is notable that when asked their preference they often opt for separate entitlements. For instance, in a meeting of 4 JFM groups in West Bengal in which both spouses were present, women wanted separate and equal shares for husbands and wives (Sarin, 1995). I found the same in Gujarat where women in some villages were refusing to become members unless they were entitled to their own share of benefits (my fieldwork, 1999). Being members in their own right is one way by which women could get such benefits directly, provided that the individual and not the household is treated as the unit for benefit sharing.

Direct membership to a CFG can also bring additional financial benefits. For instance, in some Gujarat villages, a part of the daily wage earnings from tree planting go into a savings fund. Where women are not members, the savings go into a family account (which the men effectively control).

\footnotetext{
${ }^{22}$ Guhathakurta and Bhatia (1992); and my field interviews, 1998-99.
} 
In contrast, in a few initiatives where female membership is high, savings go into separate accounts for women and men, and women can make their own decisions on how to spend this money.

Overall therefore, there are several reasons why we would expect women by and large to not cooperate voluntarily with strict closure: their high dependence on the commons, the everyday nature of this dependence and fewer alternatives for firewood and fodder; their lack of direct participation in or even consultation on rule-making, so that their concerns get neglected in the rules men frame; and their higher costs and fewer benefits from closure. Rather we would expect a higher probability of non-cooperation (e.g. breaking rules), non-voluntary cooperation (reflected e.g. in complaining), and non-voluntary non-cooperation (e.g. not participating in institutional activities due to exclusion rather than choice).

\section{(3) Non-cooperation and Non-voluntary Cooperation}

Non-voluntariness in cooperation can take several forms. While a systematic assessment of this awaits more detailed empirical analysis, my fieldwork thus far provides interesting pointers. To begin with, wherever there is strict forest closure, women dislike the rules. Some break them (noncooperation); some complain but comply (non-voluntary cooperation); and some few exit and form their own group.

\section{(i) Non-cooperation}

Almost all the villages I studied reported some cases of rule violation, at times as a frequent occurrence. Violations by men are usually for timber for self-use or sale (the latter in areas with commercially valuable trees). Violations by women are typically for firewood. Sometimes, acute need forces women into persistent altercations with the guard. ${ }^{24}$ In one Gujarat village I found that only when the guard threatened to resign did the EC agree to open the forest for a few days annually. In Agrawal's (1999) study of a van panchayat village, women constituted $70-80 \%$ of the reported offenders between 1951 and 1991, most being poor and low caste. It is notable that Agrawal suggests this may be due not only to their greater dependence on the forest, but also because the forest council dominated by high caste men applies the rules more strictly to poor, low-caste women.

\section{(ii) Non-voluntary cooperation:}

Coexistent with non-cooperation is non-voluntary cooperation. Women in some communities state they do not break rules because of a threat of beatings from husbands (Sarin, 1995; author's interviews in Gujarat, 2002). More commonly, women fear reprimand. As some men in Manchod village told my Gujarat research team: "women have to be controlled because they are liable to cut wood". Some village bodies also seek to shame husbands if their spouses break the rules (my fieldwork, 1998). Coercion can lie too in a selective harshness in applying rules, as noted in Agrawal's (1999) study cited above.

\footnotetext{
${ }^{23}$ Personal communication, NGO project officer in Gujarat, March 1995.

${ }^{24}$ E.g., Shah and Shah (1995), Singh and Kumar (1993), and Agarwal (1997a); also my field interviews during $1998-99$.
} 
Certainly women almost everywhere complain persistently about strict closures. Some of those who complain no doubt also break the rules, but many don't or do so rarely, as apparent from women's fairly systematic shift to substitute fuels, even while complaining about the negative effects of using inferior fuels. Sometimes women's complaints lead to a rule change.

After our complaints women and men had a joint meeting and decided to open the forest for a few days for firewood collection, since everyone has to cook (women to author, Asundriya village, Gujarat, 1999).

In rare cases when they find the male-made rules too exclusionary, and if additional common land is available, women choose the exit option and set up their own CFG. In one Orissa village, for example, when I asked the women why they decided to take up their own patch for protection, they responded: "If we have our own forest, we would not need to ask the men each time for a bit of wood" (Kudamunda village, Orissa, 1998). Elsewhere they were less successful. In the UP hills, for example women from Bitholi village closed off a patch of open grazing land for protection, but the men insisted on getting it reopened arguing: "What right do you have to take over men's work?" 25

\section{(iii) Non-voluntary non-cooperation}

Non-voluntary non-cooperation is best revealed in terms of participation in activities. There are several indications that women's lack of "cooperation" is not voluntary.

To begin with, women typically say that they would like to attend GB meetings if the situation were conducive, for instance, if the men invited them:

We are capable like men of doing anything, but we don't get the opportunity (women to author's research team, Bambri village, Gujarat, 2001).

Women should be encouraged to attend meetings. If they are scolded for neglecting their housework, they will never attend (women to author's research team, Boria village, Gujarat, 2001).

Coming to meetings once a month is ok. If the men permit us we can come (woman to author, Banaspur village, Karnataka, 1998)

They don't call us, so we don't go (women to author, Roopakheda village, Madhya Pradesh, 1999).

It is notable that women do attend meetings if they are specifically invited (since this legitimizes their by-passing social norms). Forest officials or NGOs have used their bargaining power with the community to increase women's participation in this way. In West Bengal's Bankura district, the District Forest Officer issued a circular stipulating that there should be a minimum of 30\% women in the general body. This raised female membership in several villages to that level (Viegas and

\footnotetext{
${ }^{25}$ Communication to the author by a group of women at a meeting at the Society for International Education and Rural Development, UP hills, 1998.
} 
Menon, 1993: 187). Again, in Haryana (northwest India), the forest department instructed its field staff to ensure that a maximum number of both men and women attend JFM meetings. The field staff would simply refuse to start meetings unless the men called the women. No excuses were accepted from the men that the women were busy with domestic chores or were unlikely to come, and women, on being invited, often turned up in strength (Sarin, 1998).

Similarly, where women become a cohesive group, they are themselves able to transcend some of the social norms. For instance, a number of rural NGOs in India have formed all-women groups outside the context of CFGs, such as savings-and-credit groups or more multi-functional ones, such as mahila mangal dals in the UP hills. Some of these group members also become CFG members. Such separate women's groups enhance women's self-confidence and experience in collective functioning in non-traditional public bodies. Sometimes, this demonstration effect alters male perceptions about women's capabilities, and eases social norms which earlier defined only the domestic as legitimate female space. The following comment to me by a woman leader in Vejpur village, Gujarat, in 1999 is illustrative and typical:

Men used to shut us up and say we shouldn't speak. Women learned to speak up in a sangathan (group). Earlier we couldn't speak up even at home. Now we can be more assertive and also go out. I am able to help other women gain confidence as well.

The presence of a larger number of women in village meetings can also help. Women in Panchmua village (Gujarat, 2001) put it clearly: "It helps to have more women because then women will not be dominated or feel shy. After all, if there is only one woman and ten men, how will she speak? Women need each other to be able to speak up. ${ }^{26}$

Another indicator of women's desire to be more active in CFG work if they had fewer constraints is their setting up their own informal protection groups when the men's groups are ineffective. I came across several such groups, especially in the UP hills and Gujarat. Where not constrained by social norms they also join fire-fighting efforts. Sometimes their vigilance alone has saved the forest (my fieldwork, 1998-99).

All this indicates that women's limited participation in the CFG's collective activities is in large part non-voluntary in nature.

\section{IMPLICATIONS FOR RESOURCE REGENERATION AND SUSTAINABILITY}

What effect do these factors have on prospects for resource protection and regeneration. To begin with, consider what we might expect. Table 1 sets out the likely outcomes of non-cooperation (NC), non-voluntary cooperation (NVC) and non-voluntary non-cooperation (NVNC), for resource sustainability.

Women's non-cooperation, in terms of breaking the forest closure rules, need not automatically have a negative effect on the state of the forest. Much depends on what is collected and how much,

\footnotetext{
${ }^{26}$ See also, Agarwal (1997b, 2000b) on the importance of a "critical mass" of women for improving their ability to cooperate and to be effective in such forums.
} 
how frequently, by what method, in what season, and so on. Firewood collection would have a neutral effect if women gathered only dried branches and fallen twigs, since that would not harm tree growth. The effect would be negative if they cut green branches or entire trees, or if their trampling through the forest damaged fresh shoots and undergrowth.

We would expect non-voluntary cooperation to have a neutral effect in so far as women follow the rules, although under duress.

And we would expect non-voluntary non-cooperation to have a negative effect in that women's absence from CFG activities means missed opportunities for better forest management and development.

In practice, at one level, many CFGs have had notable success in forest regeneration. In some cases, replanting is undertaken, but if the rootstock is intact even simply restricting human and animal entry can lead to rapid natural revival. For instance, within five to seven years of such restriction many severely degraded tracts in semi-arid India are found covered with young trees; and areas with little and declining vegetation show signs of good regeneration. In fact in most ecological zones, CFGs show such beneficial results.

Table 3 also clearly brings this out. The growing stock (tons/hectare) and mean annual increment (MAI) of woody biomass is positive in all cases, with the MAI being more than $3 \mathrm{t} / \mathrm{ha} / \mathrm{yr}$ in 8 of the 12 villages, and as high as 9.75 in Baluji na muada. Similarly, Table 4 shows that all the 19 villages have moved from degraded to fair or good quality forest. As assessed broadly on a scale of 0-5 by one of my researchers (with training in forestry) and myself, forests in 16 of the 19 villages fall in the range of 3 to 4.75 . 27

Hence if our measure of efficiency of CFG functioning is solely an improvement in the condition of the forest in relation to its situation prior to protection, and its continued regeneration, then all these CFGs and many others would pass that test. But there are two problems with this assessment. One, much of this regeneration has been achieved through a highly gender unequal sharing of the costs. Two, If our measure of efficiency is the gap between the gains realized and those realizable, then gender inequalities would tend to be associated with much less effective protection than possible.

First on costs, Tables 3 and 4 provide little support for claims that strict closure regimes are warranted on grounds of efficiency in forest regeneration. As Table 3 shows, a great deal more firewood can be extracted from 10 of these 12 forests without harming forest regeneration and sustainability. And MAI is reasonably high even when the closure is lenient. Table 4 similarly shows that on a scale of 1 to 5, although the forests with strict closure do much better, those with lenient closure are not doing badly either. In other words there need be no conflict between gender equity and efficiency. Indeed greater equity on this count would promote efficiency by reducing tendencies to rule breaking or women having to cooperate under duress.

\footnotetext{
${ }^{27}$ The assessment was made broadly, taking visual account of the density of tree growth, its age as indicated by the girth and height of trees, its overall regeneration, the presence or absence of stumps, etc. This assessment was made in major segments of the forest. Admittedly the method is a rather rough one, but it appeared adequate for our purpose, which was to obtain only a broad assessment of forest quality in the 19 villages.
} 
This is also borne out by Table 6, which presents regression results with forest quality (FQLT) as the dependent variable and the number of forest segments, the per cent of women in the EC, and the forest area per household as explanatory variables. We would expect FQLT to be negatively related to FSEG and positively related to WEC, while FAHH could go either way. The more the forest segments the more difficult it is to monitor protection. The greater is women's involvement in the CFG the better the forest quality is likely to be. On FAHH, on the one hand the more the area per household the less is the forest likely to deteriorate with extraction for basic needs. On the other hand, the more the FAHH the more difficult it would be to monitor.

\section{TABLE 6: FACTORS AFFECTING PROTECTED FOREST QUALITY}

\begin{tabular}{|c|c|c|c|c|}
\hline $\begin{array}{l}\text { Dependent Variable: } \\
\text { Method: Least Squar } \\
\text { Date: } 04 / 08 / 02 \text { Tim } \\
\text { Sample: } 119 \\
\text { Included observation }\end{array}$ & $\begin{array}{l}\text { JG(FQLT) } \\
12: 52 \\
19\end{array}$ & & & \\
\hline Variable & Coefficient & Std. Error & t-Statistic & Prob. \\
\hline $\begin{array}{c}\text { C } \\
\text { LOG(FSEG) } \\
\text { LOG(WEC) } \\
\text { LOG(FAHH) }\end{array}$ & $\begin{array}{r}0.589278 \\
-0.168182^{* *} \\
0.244106^{*} \\
0.035020 \\
\end{array}$ & $\begin{array}{l}0.449045 \\
0.071276 \\
0.134998 \\
0.042997 \\
\end{array}$ & $\begin{array}{r}1.312293 \\
-2.359583 \\
1.808222 \\
0.814468 \\
\end{array}$ & $\begin{array}{l}0.2091 \\
0.0323 \\
0.0907 \\
0.4281 \\
\end{array}$ \\
\hline $\begin{array}{l}\text { R-squared } \\
\text { Adjusted R-squared } \\
\text { S.E. of regression }\end{array}$ & $\begin{array}{l}0.455392 \\
0.346471 \\
0.159822\end{array}$ & $\begin{array}{l}\text { Mean dep } \\
\text { S.D. depe } \\
\text { F-statistic } \\
\text { Prob(F-st }\end{array}$ & $\begin{array}{l}\text { odent var } \\
\text { dent var } \\
\text { stic) }\end{array}$ & $\begin{array}{l}1.211277 \\
0.197699 \\
4.180924 \\
0.024467\end{array}$ \\
\hline
\end{tabular}

** Significant at the $5 \%$ level

* Significant at the $10 \%$ level

The results are interesting. The coefficients of both FSEG and WEC are significant and, as hypothesized, the former is negatively related to forest quality and the latter positively. The result for WEC suggests that although women's presence in ECs does not significantly affect the nature of the closure regime, it does help improve forest quality. This is probably because it enhances women's sense of involvement in the CFG, and their level of information about CFG rules and activities, information which can also flow from the EC women to other women.

This positive effect of women's presence in the EC could be enhanced further with their greater and more effective involvement in CFG activities and decision-making. In particular, this could help in three ways. One, it would help CFGs frame more acceptable rules of extraction and protection, and decrease violations. As women in the UP hills reasoned: "The male members of the committee have difficulties implementing the rules. Women could discuss these problems with the men. Perhaps more "mid-way" rules would be, in the long run, more effective... more viable" (cited in Britt, 1993: 148). Bardhan's (1999) study, although ungendered and relating to water users groups, is again a pointer to the link between rule compliance and participation in rule formulation.

Relatedly, if women had more effective voice, firewood shortages or other hardships would be 
seen as a community concern and not just the concern of individual households, or of women alone. This could pressure the CFGs to not only extract more, but also find additional solutions to firewood problems, such as allocating part of the forest to fuelwood plantations; or using the community funds to subsidize alternative fuels such as biogas. This would also increase women's voluntary participation.

Two, women's greater involvement in protection work could improve protection. For example, oftentimes the male guard or patrol can fail to notice resource depletion. In several cases, women's informal patrols in Gujarat took me on their informal patrol route and pointed out illegal cuttings which the men had missed. Part of this gender difference arises from the fact that women, as the main and most frequent collectors of forest products, are more familiar with the forest than men (Agarwal, 1997b).

Moreover, men alone in some areas find it difficult to catch transgressors. In most regions I visited in 1998-99, all-male patrols or male guards could not deal effectively with women intruders because they risked being charged with sexual harassment or molestation, especially where non-member women, or women from neighboring villages, were caught. In some incidents, women and their families registered false police cases against patrol members, or beat them up. Equally, however, women on their own find it difficult to patrol at night or confront aggressive male intruders. The most effective solution appears to be patrol teams constituted of both sexes Recognizing this, in some regions male patrol groups have inducted women, but this is atypical. 28

When women voluntarily form informal patrols, even where there is a male guard or patrol, protection efficiency can improve notably. In their study of twelve van panchayats, Sharma and Sinha (1993) found that all the four that were "robust" had active women's associations. They note (1993:173): "If the condition of the forests has improved in recent years, much of the credit goes to these women's associations". I found that even though these associations have no formal authority for forest protection, they monitor forest use, spread awareness among women of the need to conserve forests, and exert social pressure on women who violate usage rules. However, in so far as women's groups are usually informal, they lack the authority to punish offenders who still have to be reported to the formal (typically all-male) committees. This separation of authority and responsibility can undercut women's efforts. For instance, in several cases in Karnataka and the UP hills, I found that women had abandoned their efforts and violations had increased because the male EC members failed to penalize the culprits women caught. Women's formal involvement in protection would pay dividends especially (although not only) in the hills where male outmigration is high.

Three, efficiency can be increased by taking account of gender differences in preferences, say regarding when grass should be cut or which trees should be planted. I found that in the rare cases when women were consulted, they often came up with alternative, more suitable, suggestions on when the forest should be opened for grass collection, taking account, for instance, of existing stocks of grass or firewood. A case in point is Simal village (UP hills) where the men had fixed a date for grass cutting, but the women, when consulted, said: "This period is not right. We have work now and also have some dry fodder left. We should be cutting when our store of fodder is

\footnotetext{
${ }^{28}$ For figures, see Agarwal (2001).
} 
depleted." So the committee rescheduled the forest opening. 29 Women also often differ from men in their preferred tree varieties (Brara, 1987). Taking account of such gender differences in preferences, and including women in forest planning, could enhance the programme's ability to fulfill household needs and the commitment of excluded members to the initiative.

\section{IN CONCLUSION}

This paper has departed from most previous work on inequality and collective action, in several respects:

- In focusing on gender inequality as distinct from (even while interactive with) other forms of inequality, such as class, caste, ethnicity, and so on;

- In taking into account inequality stemming not only from economic endowments but also from social norms and social perceptions;

- In tracing the effect of both pre-existing inequalities and inequalities that arise from the structure of the governance institution itself; in other words, taking into account both exogenous and endogenous aspects of inequalities;

- In distinguishing between voluntary and non-voluntary cooperation (and non-cooperation) and identifying the likely effects on environmental sustainability.

Women are typically found to bear disproportionately higher costs and obtain lower benefits from closure than men. Overall, both the pre-existing and the institutionally created gender inequalities are found to reduce women's ability to cooperate voluntarily in local forest management, as well as their incentive to do so. In particular, the substantial gender gap in economic endowments, gendered social norms and perceptions, the rules governing the institution, and the power of coercion underlying gender relations (at home and in the community) significantly constrain women's voluntary cooperation. Rather these inequalities create tendencies among women toward non-cooperation, or toward non-voluntary cooperation and non-voluntary non-cooperation. Gender-related inequality (unless mitigated by specific measures) is therefore likely to be associated with low or failed cooperation, if we measure cooperation among all members of the community, rather than only among assumed unitary households.

The effect of this gender divergence in cooperation on the state of the resource, and on environmental sustainability more generally, could well be neutral on some counts but would clearly be negative on others. More particularly, the empirical evidence shows that this is an avoidable cost since both greater voluntary cooperation by women and greater gender equity in benefit-sharing can be promoted alongside better forest quality and sustainability, with less strict closure regimes and more gender-democratic CFG governance structures.

\section{REFERENCES}

Acharya, M. and Bennett, L. (1981): An Aggregate Analysis and Summary of Village Studies, The Status of Women in Nepal, II, Part 9. Kathmandu, CEDA, Tribhuvan University.

\footnotetext{
${ }^{29}$ Personal communication, Dewan Nagarkoti, Uttarakhand Sewa Nidhi, UP hills, 1998.
} 
Agarwal, B. (1984): "Rural Women and the HYV Rice Technology in India", Economic and Political Weekly, March.

(1987): "Under the Cooking Pot: The Political Economy of the Domestic Fuel Crisis in Rural South Asia”, IDS Bulletin, 18 (1): 1-22.

----- (1994): A Field of One's Own: Gender and Land Rights in South Asia, Cambridge: Cambridge University Press.

----- (1997a): “'Bargaining' and Gender Relations: Within and Beyond the Household”, Feminist Economics, 1 (5): 1-51.

(1997b): "Environmental Action, Gender Equity and Women's Participation", Development and Change, 28 (1): 1-44.

----- (2000a): “Conceptualizing Environmental Collective Action: Why Gender Matters", Cambridge Journal of Economics, 24 (3): 283-310.

--- (2000b): "Group Functioning and Community Forestry in South Asia: A Gender Analysis and Conceptual Framework", working paper no. 172, World Institute for Development Economics Research, Helsinki.

---- (2001): "Participatory Exclusions, Community Forestry and Gender: An Analysis and Conceptual Framework", World Development, 29 (10).

Agrawal, A. (1999): "State Formation in Community Spaces: Control over Forests in the Kumaon Himalaya, India", paper prepared for presentation at the University of California, Berkeley, Workshop on Environmental Politics, April 30

Akram-Lodhi, A.H. (1996): "You are not Excused from Cooking: Peasants and the Gender Division of Labour in Pakistan”, Feminist Economics, 2 (2): 87-105.

Bahuguna, V.K. (2000): "Joint Forest Management: An Instrument for Sustainable Forest Management”, paper presented at a conference on India's Forests Beyond 2000, Commonwealth Forestry Association (India), India Habitat Center, Delhi, April 19-21.

Baland, J. M. and Platteau, J.P. (1996): Halting Degradation of Natural Resources: Is there a Role for Rural Communities? Oxford: Clarendon Press.

Ballabh, V. and Singh, K. (1988): "Van (Forest) Panchayats in Uttar Pradesh Hills: A Critical Analysis", Research paper, Institute for Rural Management, Anand.

Bardhan, P. (1999): "Water Community: An Empirical Analysis of Cooperation on Irrigation in South India”, mimeo, Dept. of Economics, University of California at Berkeley.

Becker, G. S. (1965): “A Theory of the Allocation of Time”. Economic Journal 75: 493-517. 
---- (1981): A Treatise On the Family. Cambridge (MA): Harvard University Press.

Brara, R. (1987): 'Shifting Sands: A Study of Rights in Common Pastures”, Report, Institute of Development Studies, Jaipur.

Britt, C. (1993): "Out of the Wood? Local Institutions and Community Forest Management in two Central Himalayan Villages", Cornell University, Ithaca, draft monograph.

CSE (2001): "Biomass: A Smoky Problem', Health and Environment Newsletter (Center for Science and Environment, Delhi), 1(1): 6.

CWDS (1999): "From Oppression to Assertion: A Study of Panchayats and Women in Madhya Pradesh, Rajasthan and Uttar Pradesh", Center for Women's Development Studies, New Delhi.

Chopra, K. and Gulati, S. C. (1997): "Environmental Degradation and Population Movements: The Role of Property Rights", Environment and Resource Economics, 9: 383-408.

Doss, C.R. (1996): “Testing Among Models of Intrahousehold Resource Allocation”, World Development, 24 (10): 1597-1609.

Gandhi, N. and N. Shah (1991): The Issues at Stake: Theory and Practice in the Contemporary Women's Movement in India, Delhi: Kali for Women.

Goetz, A.N. (1990): "Local Heroes, Local Despots: Exploring Fieldwork Discretion in Implementing Gender Redistributive Development Policy", paper presented at the Development Studies Association Conference, Glasgow

Gold, A. and Gujar (1997): "Wild Pigs and Kings: Remembered Landscapes in Rajasthan", American Anthropologist, 99 (1): 70-84.

Guhathakurta, P. and Bhatia, K. S. (1992): "A Case Study on Gender and Forest Resources in West Bengal", World Bank, Delhi, June 16.

Guyer, J. I. and P. E. Peters (1987): "Introduction" and other papers in Conceptualizing the Household: Issues of Theory and Policy in Africa, a special issue of Development and Change 18 (2): 197-213.

Haddad, L. J. Hoddinott, and H. Alderman (1997): "Introduction: The Scope of Intrahousehold Resource Allocation Issues", in L. Haddad, J. Hoddinott, and H. Alderman (eds) Intrahousehold Resource Allocation in Developing Countries: Methods, Models and Policy. Baltimore, Maryland: John Hopkins Press.

Hart, G. (1993): "Gender and Household Dynamics: Recent Theories and Their Implications", in M.G. Quibria (ed): Critical Issues in Asian Development, Asian Development Bank and New York: Oxford University Press, 33-74. 
IDS Bulletin (1991): "Researching the Household: Methodological and Empirical Issues", 22 (1), January.

Jodha, N.S. (1986): “Common Property Resources and the Rural Poor”, Economic and Political Weekly, 21 (27): 1169-81.

Katz, E. (1999): “Intra-household Economics of Voice and Exit”, Feminist Economics, 3 (3): 25-46.

Kant, S., Singh, N. M. and Singh, K. K. (1991): “Community-based Forest Management Systems (Case Studies from Orissa)", SIDA, New Delhi; Indian Institute of Forest Management, Bhopal; and ISO/Swedforest, New Delhi, April.

Lundberg, S. and R. A. Pollak (1993): "Separate Spheres, Bargaining and the Marriage Market". Journal of Political Economy, 101 (6): 988-1010.

Mansingh, O. (1991): Community Organization and Ecological Restoration: An Analysis of Strategic Options for NGOs in Central Himalaya, with particular reference to the Community Forestry Programme of the NGO Chirag, MA dissertation in Rural Development, AFRAS, University of Sussex.

Mckean, M.A. (1986): "Management of Traditional Common Lands (Iriaichi) in Japan", in Bromley, D.W. (ed): Making the Commons Work: Theory, Practice and Policy, San Francisco, Institute for Contemporary Studies Press.

Mukerjee, R. and Roy, S. B. (1993): "Influence of Social Institutions on Women's Participation in JFM: A Case Study from Sarugarh, North Bengal”, Working Paper no. 17, IBRAD, Calcutta.

Narain, U. (1994): “Women's Involvement in Joint Forest Management: Analyzing the Issues," draft paper, May 6.

Narasimhan N. (1999): 'Women's Role in the Gram Sabha', Kurukshetra, 48 (1), 35-38.

Natrajan, I. (1995): “Trends in Firewood Consumption in Rural India”, Margin, 28 (1): 41-45.

Ostrom, E. (1990): Governing the Commons, Cambridge: Cambridge University Press.

Raju, G., Vaghela, R. and Raju, M. S. (1993): Development of People's Institutions for Management of Forests, Ahemdabad, VIKSAT

Raju, M.S. (1997): "Seeking Niches in Forest Canopy: An Enquiry into Women's Participation", mimeo, Ford Foundation, New Delhi.

Ravindranath, N.H., K.S. Murali, and K.C. Malhotra (2000): Joint Forest Management and Community Forestry in India: An Ecological and Institutional Assessment, New Delhi: Oxford and IBH Publishing Co. Pvt. Ltd. 
Roy, S. B., Mukerjee, R. and Chatterjee, M. (c1992): "Endogenous Development and Gender Roles in Participatory Forest Management”, IBRAD, Calcutta.

Roy, S. B. et al. (1993): "Profile of Forest Protection Committees at Sarugarh Range, North Bengal", IBRAD Working Paper No. 16.

Samuelson, P. A. (1956): "Social Indifference Curves", Quarterly Journal of Economics, 70 (1): 122.

Sarin, M. (1998): Who is Gaining? Who is Losing? Gender and Equality Concerns in Joint Forest Management, New Delhi: Society for Promotion of Wasteland Development

---- (1995): "Regenerating India's Forest: Reconciling Gender Equity and Joint Forest Management", IDS Bulletin, 26 (1): 83-91

Saxena, S., Prasad, R., and V. Joshi (1995): "Time Allocation and Fuel Usage in Three Villages of the Garhwal Himalaya, India", Mountain Research and Development, 15 (1): 57-67.

Seiz, J. (2000): "Game Theory and Bargaining Models", Elgar Companion to Feminist Economics, Cheltenham, Elgar Publishing House, 379-390.

Sen, A. K. (1990): "Gender and Cooperative Conflicts", in Tinker, I. (ed) Persistent Inequalities: Women and World Development, New York: Oxford University Press, 123-49.

Sen, I. (1988): "Class and Gender in Work Time Allocation”, Economic and Political Weekly, 23 (33): 1702-6.

Sethi, R. and E. Somanathan (2001): 'Norm Compliance and Strong Reciprocity', paper presented at a workshop on 'The Structure and Evolution of Strong Reciprocity', Santa Fe Institute, New Mexico, March 9-11.

Shah, M. K. and P. Shah (1995): "Gender, Environment and Livelihood Security: An Alternative Viewpoint from India”, IDS Bulletin, 26 (1): 75-82.

Sharma, A. and Sinha, A. (1993): "A Study of the Common Property Resources in the Project Area of the Central Himalaya Rural Action Group", mimeo, Indian Institute of Forest Management, Bhopal, Madhya Pradesh.

Singh, M. (1997): "Lumping and Levelling: Gender Stereotypes and Joint Forest Management," paper presented at the seminar on "The Social Construction of Community Participation in Joint Forest Management", organized by the University of Edinburgh and Indian Council of Forestry Research and Education, India International Centre, April 9-11. 
Singh, A. and N. Burra (eds) (1993): Women and Wasteland Development in India, New Delhi: Sage Publications.

Singh, N. and Kumar, K (1993): "Community Initiatives to Protect and Manage Forests in Balangir and Sambalpur Districts", Swedish International Development Agency, New Delhi.

Smith, K. R., A.L. Agarwal and R.M. Dave (1983): “Air Pollution and Rural Fuels: Implications for Policy and Research", Resource Systems Institute, East-West Center, Honolulu, Hawaii.

Tata Energy Research Institute (TERI) (1995): "Community Participation in Van Panchayats of Kumaon region of Uttar Pradesh”, Paper No.1, Part I, TERI, Delhi.

Thomas-Slater, B. and N. Bhatt (1994): "Land, Livestock, and Livelihoods: Changing Dynamics of Gender, Caste, and Ethnicity in a Nepalese Village", Human Ecology, 22 (4): 467-494.

UNDP (2001): "Decentralisation in India: Challenges and Opportunities", HRDS Discussion Paper No. 1, United Nations Development Programme, Delhi.

Venkateshwaran, S. (1992): Living on the Edge: Women, Environment and Development, New Delhi, Friedrich Ebert Stiftung.

Viegas, P. and Menon, G. (1991): "Forest Protection Committees of West Bengal: Role and Participation of Women", paper prepared for the ILO Workshop on "Women and Wasteland Development", International Labour Organization, New Delhi 9-11 January.

White, T. A. and Runge, C. F. (1994): "The Emergence and Evolution of Collective Action: Lessons from Watershed Management in Haiti”, draft paper, Center for International Food and Agricultural Policy, University of Minnesota. 
APPENDIX TABLE 1: DESCRIPTIVE STATISTICS

$\begin{array}{lccccc} & \text { CLR } & \text { FAHH } & \text { FSEG } & \text { FQLT } & \text { WEC } \\ \text { Mean } & 0.473684 & 1.543158 & 2.789474 & 3.421053 & 24.24737 \\ \text { Median } & 0.000000 & 1.200000 & 3.000000 & 3.250000 & 18.20000 \\ \text { Maximum } & 1.000000 & 4.250000 & 6.000000 & 4.750000 & 36.40000 \\ \text { Minimum } & 0.000000 & 0.190000 & 1.000000 & 2.500000 & 15.40000 \\ \text { Std. Dev. } & 0.512989 & 1.272164 & 1.474937 & 0.687450 & 7.606457 \\ \text { Skewness } & 0.105409 & 0.989993 & 0.585406 & 0.487373 & 0.599799 \\ \text { Kurtosis } & 1.011111 & 2.759230 & 2.493887 & 2.269413 & 1.853250 \\ & & & & & \\ \text { Jarque-Bera } & 3.166764 & 3.149502 & 1.288003 & 1.174742 & 2.180305 \\ \text { Probability } & 0.205280 & 0.207059 & 0.525187 & 0.555787 & 0.336165 \\ & & & & & \\ \text { Observations } & 19 & 19 & 19 & 19 & 19\end{array}$

APPENDIX TABLE 2: CORRELATION MATRIX

$\begin{array}{lccccc} & \text { CLR } & \text { FAHH } & \text { FSEG } & \text { FQLT } & \text { WEC } \\ \text { CLR } & 1.000000 & -0.199918 & -0.521706 & 0.466388 & 0.132035 \\ \text { FAHH } & -0.199918 & 1.000000 & 0.309483 & -0.157717 & -0.336002 \\ \text { FSEG } & -0.521706 & 0.309483 & 1.000000 & -0.510426 & -0.254580 \\ \text { FQLT } & 0.466388 & -0.157717 & -0.510426 & 1.000000 & 0.497976 \\ \text { WEC } & 0.132035 & -0.336002 & -0.254580 & 0.497976 & 1.000000\end{array}$

